\title{
Література
}

1. Ельницкий К. Курс дидактики: [пособие для учебных заведений, в которых преподается педагогика] / Кирилл Ельницкий - СПб. : Изд. М. М. Гутзаца, 1909. - 173 с. 2. Каптерев П. Ф. Избранные педагогические сочинения / Петр Федорович Каптерев; под ред. А. М. Арсеньева. - М. : Педагогика, 1982. - 704 с. 3. Каптерев П. Ф. О школьном самоуправлении и школьной дисциплине / П. Ф. Каптерев // Педагогическая мысль. - 1921. - № 1. - 4. - С. 19-31. 4. Лесгафт П. Ф. Избранные педагогические сочинения / Петр Францевич Лесгафт. - М. : Педагогика, 1988. - 400 с. 5. Миропольский С. И. Дидактические очерки. Ученик и воспитывающее обучение в народной школе / Сергей Иеренеевич Миропольский. - СПб: Типография И. Н. Скороходова, 1890. - 78 с. 6. Пирогов Н. И. Избранные педагогические сочинения / Николай Иванович Пирогов; сост. А. Н. Алексюк, Г. Г. Савенок. - М. : Педагогика, 1985. - 496 с. 7. Сухомлинский В. А. Избранные произведения в 5 томах / Василий Александрович Сухомлинский. - К. : Рад. школа, 1980. - Т. 5. - 680 с. 8. Юркевич П. Д. Курс общей педагогики с приложениями / Памфил Даниилович Юркевич. - М., 1869. - 404 с. 9. Яновский К. П. Мысли о воспитании и обучении / Кирилл Петрович Яновский. - СПб. : Тип. И. Н.Скороходова, 1900. - 299 с. 10. Центральний державний історичний архів м. Київ. Ф 707 Управление попечителя Киевского учебного округа Оп. 143. Спр. 60 «Копии протоколов заседаний педагогического совета прогимназий за 1 полугодие 1891 года». - 1891. - 458 арк. 11. Центральний державний історичний архів м. Київ. Ф 707 Управление попечителя Киевского учебного округа. Оп. 317. Спр. 503 «Протоколы заседаний за 1903 год». - 1903. - 113 арк.

Наталія Зайцева

\section{ОСОБЛИВОСТІ ЗМІСТУ ДВОМОВНОГО НАВЧАННЯ В СЕРЕДНІХ ШКОЛАХ США}

Зайцева Н. Г. Особливості змісту двомовного навчання в середніх школах США.

У статті розглянуто особливості змісту двомовного навчання в середній освіті США. На основі аналізу змісту двомовного навчання в середніх школах Сполучених Штатів Америки виокремлено найважливіші його складники, розкрито специфіку полікультурного розвитку учнів в навчальних закладах США.

Ключові слова: двомовне навчання, зміст двомовного навчання, багатомовний розвиток, полікультурний розвиток, акультурація.

Зайцева Н. Г. Особенности содержания двуязычного обучения в средних школах США.

В статье рассмотрены особенности содержания двуязычного обучения в среднем образовании США. На основе анализа содержания двуязычного обучения в средних школах Соединенных Штатов Америки выделены самые важные его составляющие, раскрыта специфика поликультурного развития в учебных заведениях США.

Ключевые слова: двуязычное обучение, содержание двуязычного обучения, многоязычное развитие, поликультурное развитие, аккультурация.

Zaitseva N. G. The features of the content of bilingual education in secondary schools of the USA.

The article deals with the review of the content of secondary bilingual education in the USA. On the basis of the analysis of the content of bilingual education in the USA secondary schools its most important components and the specifics of pupils' polycultural development were identified.

Key words: bilingual education, content of bilingual education, multilingual development, multicultural development, acculturation.

Розвиток полікультурності і багатомовності в контексті світових трансформацій зумовлює поширення двомовного навчання як засобу надання загальної і подальшої освіти учням, які мають різну національну приналежність. Сполучені Штати Америки вважають однією 3 найбільш багатомовних країн світу. Недарма цю країну порівнюють із «салатним блюдом», де представлено багато націй (щонайменше 322) [3]. Потреба надання якісної освіти учням будьякої етнічної приналежності спричинила необхідність запровадження двомовного навчання в освітніх закладах країни. Спираючись на визначення вітчизняних та зарубіжних науковців, феномен двомовного навчання в умовах американської школи ми можемо трактувати як цілеспрямований процес формування у школярів двомовності, або здатності послуговуватися в 
житті двома мовами завдяки опануванню змісту загальноосвітніх предметів 3 використанням двох мов задля одночасного вдосконалення знань з рідної й іноземної (нерідної) мов.

Про численні, але розрізнені спроби запровадження двомовного навчання на американському континенті від часів створення перших колоній зазначають у своїх дослідженнях К. Овандо (C. Ovando), С. Крашен (Stephen D. Krashen) та інші американські науковці. Розвиток двомовного навчання як соціально-педагогічного явища зафіксовано в США у другій половині $\mathrm{XX}$ ст. [7]. Проблема дослідження особливостей змісту двомовного навчання була тоді на часі, залишається актуальною зараз і потребує постійного вдосконалення через перманентне прагнення до пошуку все більш ефективних його форм.

Україна теж $є$ багатонаціональною країною, тому і для неї $є$ важливим розв'язання питання запровадження двомовного навчання, визначення складників змісту такого навчання для ефективного його функціонування.

Проблемою двомовного навчання, визначенням особливостей його змісту опікувалися багато зарубіжних та вітчизняних дослідників: К. Бейкер (Baker С.), Дж. Бланко (Blanco J.), М. Бьорнс (Burns M.), У. Вайнрайх (Weinreich U.), О. Гарсія (Garcia O.), Д. С. Енрайт (Enright J.) та М. Л. МакКлоскі (McCloskey М.), Дж. Каммінс (Cummins J.), С. Крашен (Krashen S.), Л. Малаж (Malarz L.), Б. Перес (Pérez B.), К. Ролстад (Rolstad K.) та Дж. Мак-Свон (McSwan J.), Т. Скутнаб-Кангас (Skutnabb-Kangas T.), Ф. Фіцпатрік (Fitzpatrick F.), Дж. Фішман (Fishman J.), B. Фтенакіс (Fthenakis W.), Дж. Хамерс (Hammers J.), Р. Хорн (Horn R.), Т. Бондарчук, О. Літвінов, О. Товчигречка та ін.

Мета статті: визначити найважливіші особливості змісту двомовного навчання в США.

Двомовне навчання - це засіб засвоєння учнями змісту загальноосвітніх предметів двома мовами. Метою двомовних шкіл $є$ забезпечення учнів, незалежно від їхньої національної приналежності, якісною освітою, що не поступалася б своїм рівнем освіті, яку отримують учні мовної більшості в одномовних класах.

Розглянемо і порівняємо зміст двомовного навчання деяких американських шкіл різних штатів. Більшість шкіл у США, у яких запроваджується двомовне навчання, носять назву інтернаціональних.

Розглянемо для початку штат Каліфорнія (захід країни), де у м. Сан-Франциско функціонує німецько-американська інтернаціональна школа. Трансдисциплінарна програма школи грунтується на стандартах Міжнародної організації бакалавріату (International Baccalaureate Organization) штату Каліфорнія i німецькомовних країн, розроблена Міжнародним бакалавріатом (International Baccalaureate), охоплює два курси: вступний для 5 класу і основний для 6-8 класів.

Двомовне навчання в цій школі починається з дошкільної ланки і продовжується до 8 класу середньої школи. Учні навчаються за двосторонніми двомовними програмами (two-way bilingual programs). У процесі використання таких програм учні розвивають компетентність відразу у двох мовах, бо мають відразу дві мови - англійську та другу мову засобами опанування змісту предметів. Етнічний склад учнів також не однорідний, зазвичай клас складається 3 половини носіїв англійської мови і половини носіїв іншої виучуваної мови. Метою двомовного навчання в школі є виховання впевненої в собі, здатної поважати інших, творчої, відповідальної особистості, яка навчається протягом усього життя і вміє глобально мислити.

Вступний курс середньої двомовної школи складається 3 обов'язкових предметів і предметів за вибором (елективних).

Обов'язковими предметами є: англійська мова, рідна мова (англійська або німецька), природничі науки (ї викладають англійською мовою), фізичне виховання, образотворче мистецтво, музика, танці та інші види мистецтва, які викладають двома мовами, консультації надають двома мовами.

До елективних предметів відносять: іноземні мови (французьку або іспанську), математику, гуманітарні науки, які викладають англійською і німецькою мовами.

Основний курс (6-8 кл.) містить: обов'язкові предмети (англійська мова, рідна мова (англійська або німецька), фізичне виховання (викладають двома мовами), консультації (двома мовами)) та елективні предмети (математика (викладають англійською і німецькою), гуманітарні науки (англійською і німецькою), іноземні мови (французька або іспанська), образотворче мистецтво, музика, танці та інші види мистецтва, які викладають двома мовами). 
Школа використовує інтердисциплінарний комплексний підхід до навчання (наявність міжпредметних зв'язків, узгодженість підходів до навчання), інтегрований підхід (передбачає інтеграцію знань 3 кількох дисциплін, використання ефективних прийомів і методів навчання), концептуальні (теоретично зумовлені) засади навчання мов, розвиває комунікативні навички учнів, міжкультурну компетентність, почуття поваги до інших культур, уміння користуватися комп’ютерними технологіями, виховує позитивне ставлення до навчання тощо [9]. Після закінчення середньої школи учні продовжують навчання у вищій школі, яку вони обирають самостійно.

На заході країни функціонують ще двомовні школи з другою французькою, китайською, японською та іншими мовами поряд з американською англійською [5].

Ознайомимося з однією з двомовних шкіл штату Віргінія (схід країни). Діти у двомовних класах школи навчаються за програмою подвійного мовного занурення (dual immersion). Такі програми призначені для учнів, які є представниками мовної більшості і мовної меншості, задля опанування ними двох мов. Одна мова не замінюється іншою. Основною метою цих програм $€$ досягнення учнями високого академічного рівня мовної компетентності в обох мовах та повага до культурного розмаїття у світі. Більшість таких програм використовують на рівні початкової школи, але інколи їх продовжують застосовувати і в середній школі. Дуже часто програми подвійного занурення (dual immersion) ототожнюють із двосторонніми двомовними програм (two-way bilingual programs), але вони не в кожній ситуації $є$ подібними. Програми подвійного занурення (dual immersion) не завжди розраховані одночасно на учнів мовної меншості і мовної більшості на відміну від двосторонніх двомовних програмам (two-way bilingual programs). До складу вищезазначених класів зараховуються англомовні й іспаномовні учні. Навчання починається із занять у підготовчій групі, де навчаються діти до 8 років. Серед них є такі, які ще з дитячого садка займалися за іспано-англійськими двомовними програмами, тому подальше навчання їм дається легше, ніж учням, які тільки-но розпочали займатися у двомовних класах.

Заняття в середній двомовній школі поряд з іншими предметами передбачають вивчення англійської та іспанської мов. Математику вивчають двома мовами. У першій половині дня заняття в школі проходять іспанською мовою, у другій половині дня американською англійською. Учитель двомовного навчання в класі - емігрант з Пуерто-Ріко, який володіє іспанською й англійською мовами. Зазвичай цінують дипломованих учителів, але іноді, коли немає іншого вибору через нестаток таких фахівців, приймають на роботу людей без диплома, які $є$ носіями тієї чи тієї мови або володіють відразу двома мовами. Суть занять для учнів полягає в тому, щоб засвоїти навчальний зміст предметів і «швидко схопити другу мову», не забуваючи при цьому свою рідну. Найчастіше за все використовують груповий або індивідуальний підхід до навчання, дітей «занурюють» в іншомовне середовище, де вони співають, танцюють, роблять різні вироби на уроках праці, при цьому спілкуються i допомагають один одному, взаємодіючи у процесі навчання, і поступово засвоюють зміст загальноосвітніх предметів. Заняття періодично ускладнюються згідно з рівнем опанування школярами другої мови. У результаті навчання учні мовної більшості здобувають міцні знання 3 іспанської мови, а учні мовної меншості опановують американську англійську на досить високому соціальному й академічному рівні. Причому помічено, що іспаномовні діти мають кращі успіхи в навчанні у порівнянні з англомовними [1]. На нашу думку, це можна пояснити тим, що іспаномовні діти мають сильнішу мотивацію до засвоєння другої мови та змісту загальноосвітніх предметів, бо їм необхідно соціалізуватися в іншомовному середовищі, стати мобільними і конкурентоздатними. Освіта для них є запорукою успіху на ринку праці.

На сході країни ще функціонують двомовні школи з другою французькою, німецькою та іншими мовами поряд з американською англійською.

У штатах Небраска (північ країни), Арканзас (південь країни), Делавер (схід країни) у школах навчаються тільки за одномовними програмами. Цим вони суттєво відрізняються від більшості штатів країни, які прагнуть до розвитку полікультурності і багатомовності. Штат Віргінія фінансує тільки одномовні навчальні програми, тоді як штати Мічиган (північний схід країни) і Нью-Мексико (південь країни) фінансують суто двомовні навчальні програми і тим прагнуть до розвитку культурного і мовного багатоманіття [6].

У штатах Вашингтон (північний захід), Техас (південь), Іллінойс (північний схід) та багатьох інших штатах розповсюдженими є перехідні двомовні програми (trasitional bilingual program), які 
передбачають заняття рідною мовою учня доти, доки він не опанує англійську. Після того, як учень засвоїв англійську мову, заняття проводять тільки цією мовою. Навчання рідної мови припиняється, тому таку форму навчання важко назвати демократичною i найбільш продуктивною. Три роки учні отримують завдання рідною мовою у процесі вивчення англійської. Учителі навчають школярів говорити, читати та розвивають їхню письмову грамотність. Учні спираються на рідну мову тільки для переходу на англійську, поступово відбувається заміна цінностей, діти забувають свою рідну мову, що завжди негативно впливає на особистість.

У Каліфорнії (захід), Нью-Йорку (північний схід) і багатьох інших штатах США у школах діти навчаються за двосторонніми двомовними програмами (two-way bilingual programs), які $\epsilon$ дуже популярними, вважаються найефективнішими з усіх двомовних програм, але потребують найбільшого фінансування i компетентних двомовних учителів. Двосторонні двомовні програми передбачають вивчення шкільного матеріалу в однаковому співвідношенні рідною і другою мовами учнів.

Можемо зробити висновок, що в найбільших за чисельністю жителів штатах (Нью-Йорк, Каліфорнія та ін.) розповсюдженими є двосторонні двомовні програми, які, на думку фахівців, $\epsilon$ найбільш ефективними, а тому престижними, але й затратними, бо потребують посиленого фінансування та запрошення кваліфікованих учителів, що під силу зробити жителям та керівництву зазначених штатів. У багатьох інших штатах країни, які не в змозі профінансувати дорогі проекти та забезпечити належний рівень функціонування двомовних програм такого типу, розповсюдженими $\epsilon$ програми 3 низьким рівнем ефективності, як-то: програми подвійного занурення, перехідні двомовні програми, одномовні тощо. Найбільш розповсюдженими мовами меншин, які задіяні у двомовних програмах, $є$ : іспанська (через найбільшу кількість іспаномовних емігрантів у США), німецька, французька, східні та ін. мови.

За результатами досліджень Міжкультурної асоціації наукового розвитку (Intercultural Development Research Association) практично всі двомовні школи США використовують кілька підходів до оцінювання двомовних учнів, зокрема оцінювання їхньою рідною мовою. Високі академічні стандарти оцінювання застосовуються щодо всіх учнів, зокрема до учнів з обмеженим володінням англійською мовою (LEP). Учителі відчувають відповідальність за всіх школярів і часто використовують індивідуальний та груповий підхід у їх навчанні та оцінюванні [8].

Для оцінювання рівня знань двомовних школярів використовуються тести із завданнями рідною мовою учнів, тести із завданнями, які супроводжуються описовими поясненнями та очікуваними відповідями. Існують описові характеристики та шкала оцінювання для кожного тестового завдання. Цей вид тестування має назву Multiple choice, його застосовують під час оцінювання знань із різних предметів [4].

Опанування другої мови має проходити паралельно з процесом акультурації учнів. Систематизуємо етапи засвоєння другої мови і акультурації у цій мові, узявши за основу позицію Л. Малаж (Malarz L.) [2, с. 2].

\begin{tabular}{|l|l|}
\hline \multicolumn{1}{|c|}{ Акультурація } & \multicolumn{1}{|c|}{ Опанування другої мови } \\
\hline $\begin{array}{l}\text { Eman 1. Нова культура майже недоступна. } \\
\text { Відчувається постійна невпевненість }\end{array}$ & $\begin{array}{l}\text { Новою мовою оперувати дуже важко. Конфлікт } \\
\text { поколінь очевидний, коли діти вчаться швидше за } \\
\text { батьків }\end{array}$ \\
\hline Eman 2. Нова культура функціонально зрозуміла & Нова мова починає набувати комунікативного смислу \\
\hline $\begin{array}{l}\text { Eman 3. Проходить акультурація 3 поступовими } \\
\text { змінами і адаптацією до нової культури }\end{array}$ & $\begin{array}{l}\text { розвитком грамотності в рідній мові } \\
\text { розвивається грамотність у другій мові }\end{array}$ \\
\hline $\begin{array}{l}\text { Eman 4. Аспекти життя особи стають } \\
\text { бікультурними, тобто людина відчуває себе } \\
\text { однаково комфортно в межах двох культур }\end{array}$ & $\begin{array}{l}\text { Досягається грамотність володіння другою мовою } \\
\text { майже як першою (рідною) }\end{array}$ \\
\hline $\begin{array}{l}\text { Eman 5. Друга культура стає «комфортною», хоча } \\
\text { своя власна продовжує бути важливою }\end{array}$ & Друга мова стає застосовуваною нарівні з першою \\
\hline
\end{tabular}

У таблиці продемонстровано, що процес опанування другої мови не може бути відірваним від процесу акультурації, тобто пізнання учнями і адаптації до іншої культури. Ці процеси паралельні і тісно взаємопов'язані.

Розглядаючи різні школи і напрямки їхньої роботи, можемо засвідчити, що двомовні програми, за якими навчаються учні в школах США, мають досить багато відмінних рис, хоча, звичайно, є певні норми, яких намагаються дотримуватися всі навчальні заклади країни. Усі 
двомовні школи протягом того чи іншого проміжку часу для викладання учням загальноосвітніх предметів використовують дві мови у різній пропорційності, залежно від видів двомовних програм, які вони обрали. Вид двомовних програм найчастіше обирають місцеві органи влади залежно від національного складу населення того чи того регіону та їхнього фінансового становища. Нині у більшості шкіл Сполучених Штатів спостерігається тенденція до паралельного розвитку полікультурності й багатомовності, але в деяких штатах країни використовують одномовні програми, скорочують уроки вивчення іноземних мов, намагаючись тим самим зберегти фінансову базу освіти. Отже, дітей, як правило, позбавляють якісної двомовної і загальної освіти.

Отже, найбільш розповсюдженими особливостями змісту двомовних програм середньої школи США можна назвати: 1) спрямованість двомовних програм на забезпечення всіх учнів якісною освітою; 2) використання двох мов у різному співвідношенні для засвоєння учнями змісту немовних загальноосвітніх предметів (найчастіше математики, гуманітарних наук, різних видів мистецтва, фізичної культури), проведення консультацій зі школярами; 3) використання ефективних прийомів і методів навчання, концептуальних засад навчання мов; 4) розвиток високого академічного рівня мовної компетентності учнів в обох мовах; 5) використання двомовними школами декількох підходів до оцінювання двомовних учнів, зокрема оцінювання їхньою рідною мовою, 6) застосування високих академічних стандартів оцінювання за тестовими технологіями щодо всіх учнів, незалежно від їхньої національної приналежності; 7) сприяння паралельному розвитку полікультурності й багатомовності у двомовних школах тощо.

Використання двомовного навчання є однією з провідних тенденцій розвитку змісту освіти шкіл США в останній третині XX ст. Запровадження у зміст освіти двомовних програм розглядається як засіб підвищення шкільної успішності, розвитку рідної мови, часто перехідний етап до навчання англійською мовою, умова підвищення соціального статусу учнів, реалізація їхніх прав, основа для полікультурного розвитку учнів.

\section{Література}

1. Bilingual education in the USA. - [Електронний ресурс]. - Режим доступу: www.youtube.com/watch? $=88 \mathrm{vxOj} 8 \mathrm{CgKU}$. 2. Malarz L. Bilingual Education: Effective Programming for Language-Minority Students. [Електронний pecypc] / L. Malarz. - Режим доступу: http://www.ascd.org/publications/curriculum_handbook/413/chapters/Bilingual_Education@

Effective_Programming_for_Language-Minority_Students.aspx 3. New world Ecyclopedia. - [Електронний peсурс]. - Режим доступу: http: //www. nev. world ecyclopedia.org/ entry/ Bilingual_education. 4. New York State Teacher Certification Examinations. - [Електронний pecypc].Режим доступу: http: //www.nystce.nesinc.com /PDFs/NY_fld028_prepguide. pdf 5. Raising bilingual children. - [Електронний pecypc]. - Режим доступу: http://www.raising-bilingualchildren.com/basics/language-stimulation/bilingual-schools/usa/ 6. Requirements for the Education of Language Minority Children. - [Електронний pecypc]. - Режим доступу: http://www.users.interport.net/r/e /readinst/50state.html 7. San Miguel Guadalupe. Contested Policy: The Rise and Fall of Federal Bilingual Education in the United States, 1960-2001 / Guadalupe San Miguel. - College Station, TX, USA: University of North Texas Press, 2004. - 168 p. 8. Successful Bilingual Education Programs. - [Електронний ресурс]. Режим доступу: http://www.idra.org/IDRA_Newsletter/January_2002_Self_ Renewing_Schools Leadership/Successful_Bilingual_Education_Programs/ 9. The German-American International School (GAIS). - [Електронний ресурс]. - Режим доступу: http://www.gais.org/

\section{ЗАСАДНИЧІ ПРИНЦИПИ ІСНУВАННЯ КИЇВСЬКОГО НАВЧАЛЬНОГО ОКРУГУ В ПЕРІОД 1833-1834 рр. УКАЗИ ІМПЕРАТОРА ТА ЦИРКУЛЯРИ МІНІСТРА НАРОДНОЇ ОСВІТИ (за матеріалами «Журнала министерства народного просвещения»)}

Кільова Г. О. Засадничі принципи існування Київського навчального округу в період 18331834 рр. Укази імператора та циркуляри міністра народної освіти (за матеріалами «Журнала министерства народного просвещения»).

У статті розглянуто функціонування Київського навчального округу і найважливіші державні документи, що визначають його устрій. До них належать укази імператора, 